\title{
A novel POU domain gene, zebrafish pou2: expression and roles of two alternatively spliced twin products in early development
}

\author{
Hiroyuki Takeda, ${ }^{1,2,4}$ Takashi Matsuzaki, ${ }^{1,3}$ Toru Oki, ${ }^{1}$ Terumi Miyagawa, ${ }^{1}$ and Hiroshi Amanuma ${ }^{1}$ \\ ${ }^{1}$ Laboratory of Gene Technology and Safety, The Institute of Physical and Chemical Research (RIKEN), Tsukuba 305, Japan
}

POU domain proteins are a large family of transcriptional regulatory proteins, many of which are implicated in the control of gene expression during early development. We describe here the cloning and expression of zebrafish pou2, a novel POU domain gene related to the mouse germ-line-specific transcription factor oct-3. Zebrafish pou2 is maternally expressed, and the transcripts are present from the one-cell stage to the gastrula stage. In situ hybridization analyses revealed that the transcripts were present in all blastomeres until the midblastula stage and that the expression was restricted to the epiblast during gastrulation. We found that alternatively spliced transcripts, $t$-pou2 RNAs, were also expressed in the embryos. In contrast to the Pou2 product, the t-Pou2 product lacks DNA-binding activity because of its incomplete POU domain structure. To examine the roles of the Pou2 and t-Pou2 products, we increased their expression in the embryo by microinjection of synthetic pou2 and $t$-pou2 RNAs into the fertilized eggs at the one-cell stage. Most embryos that developed from the eggs injected with pou2 RNA did not show any obvious developmental defects. In contrast, overexpression of the t-Pou2 product greatly affected the embryonic development: There was strong developmental retardation or arrest due to the incomplete gastrulation. In the affected embryos, expression of zebrafish $T$ gene was reduced and the hypoblast formation was disturbed. Temporal and spatial expression patterns and the effects of overexpression of these products on development are consistent with the idea that the Pou 2 and t-Pou 2 proteins are involved in early development of zebrafish embryos. They may be involved in the proliferation of blastomeres in undetermined state at the blastula stage and/or the early cell commitment events at the gastrula stage. Also, our results indicate that different products generated as a result of alternative splicing from the same gene possess distinct functional capacities.

[Key Words: POU domain gene; oct-3; stem cell; zebrafish embryo; commitment; gastrulation; alternative splicing]

Received June 30, 1993; revised version accepted November 22, 1993.

During embryonic development of vertebrates, pluripotent stem cells are allocated to separate lineages and each cell lineage pursues a limited and stereotyped cell fate. Eventually, dividing cells can autonomously maintain commitments to their lineages, as shown by studies of their development in clonal cultures (Rutz and Hauschka 1982), or by transplanting them singly to new positions in the embryo (Wylie et al. 1987). Commitment could depend on the activity of a relatively few specific regulatory genes-"lineage switching" genesfor example, the MyoD gene (Davis et al. 1987; Hopwood et al. 1989). However, most of the vertebrate regulatory

Present addresses: ${ }^{2}$ Department of Molecular Biology, School of Science, Nagoya University, Chikusa-ku, Nagoya 464-01, Japan; ${ }^{3}$ Yoshizato Morhomatrix Project, ERATO (Exploratory Research for Advanced Technology), JRDC (Research Development Corporation of Japan), HigashiHiroshima, 724-05 Japan.

${ }^{4}$ Corresponding author. proteins isolated so far, such as those containing homeo box, paired box, and helix-loop-helix structure, are expressed in the embryos after gastrulation, a period when cell fates become determined. The earliest cell commitment event that occurs at around gastrulation is not fully understood at present.

In an effort to isolate regulatory genes active at earlier stages in vertebrate development, investigators have recently focused on transcription factors that are expressed only in toti- or pluripotent cells such as embryonic stem (ES) cells and inner cell mass in mammals. The first regulatory gene identified in this way is the murine oct-3 gene whose expression is restricted to the female germ line and to totipotent and pluripotent stem cells before gastrulation (Okamoto et al. 1990; Rosner et al. 1990; Schöler et al. 1990). oct-3 is also expressed in undifferentiated embryonic carcinoma cells and is down-regulated during retinoic acid-induced differentiation /Oka- 
moto et al. 1990; Rosner et al. 1990). The oct-3 gene belongs to a large family of POU domain genes. Genes of this family encode a diverged homeo domain as part of a structure referred to as the POU domain. It consists of a 75-amino-acid POU-specific domain and a 60-aminoacid POU homeo domain, both of which are required for high-affinity binding to the octamer motif (ATTTGCAT; for review, see Rosenfeld 1991). Other members of this family are also expressed in undetermined embryonic cells. The Tst-1/SCIP/oct- 6 gene product appears early in development in the inner cell mass of mouse embryos, but subsequently is expressed in specific cell types such as testis and myelinating glia (He et al. 1989; Monuki et al. 1990; Schöler et al. 1990; Suzuki et al. 1990). Xenopus laevis oct-60 is expressed as a maternal transcript, and the protein product of this gene is present in oocytes and early embryos until the gastrula stage (Hinkley et al. 1992; Whitfield et al. 1993). Thus, one possible role of POU domain genes may be to maintain cells in an undetermined state in preparation for future developmental signal.

To characterize the early events in cell-fate determination, we use zebrafish (Brachydanio rerio), a vertebrate with a number of advantages for developmental study (Kimmel 1989). In addition, zebrafish embryos are suitable for studies of the mechanism involved in the determination of blastomeres, because cell commitment occurs later in development as in mammals. Although the first three cleavages roughly define the three principal adult body axes in zebrafish embryos, ventral-dorsal, left-right, and anterior-posterior /Strehlow and Gilbert 19931, it is widely accepted that the cell-type determination does not occur before the beginning of gastrulation. If a clone is labeled by injection of tracer dye at the midblastula stage the progeny will form a mixture of cell types such as neurons, muscle cells, and epidermis; but if the labeling is done after the onset of gastrulation, the progeny of a single cell will only become a single cell type (Kimmel and Warga 1986; Ho 1992; Ho and Kimmel 1993). Furthermore, Lin et al. (1992) have shown that a small number of cells from blastula-stage embryos, when transplanted into other blastula-stage embryos, participated in the formation of many cell types including a germ line in the recipient.

In this report we describe molecular cloning and characterization of a novel zebrafish POU domain gene, pou2, whose transcripts are present from oocytes to blastula-stage embryos and are down-regulated during gastrulation. To study the function of the Pou2 protein product in vivo, we microinjected synthetic pou2 RNAs into fertilized zebrafish eggs and examined the effects on development.

\section{Results}

\section{Isolation of a novel POU domain cDNA}

To isolate novel POU domain genes expressed at early stages, we first looked for oct-3-related genes. We amplified DNA fragments using zebrafish genomic DNA as a template by polymerase chain reaction (PCR) to get oct- 3-related DNA fragments. The primers were designed based on the amino acid sequences of the amino- and carboxy-terminal portions of the murine Oct-3 POU domain. After amplification, fragments of the predicted size $(\sim 360 \mathrm{bp})$ were cloned and sequenced. One fragment, GP-3, showed $\sim 80 \%$ amino acid sequence similarity to the oct-3 gene and was used as a probe to screen the cDNA library made from the poly $(A)^{+}$RNA of early neurula embryos. We obtained four independent positive clones, each containing the same open reading frame with a typical POU domain sequence. A composite sequence was reconstituted by combining two of them at the unique NcoI site, and this POU domain cDNA was designated as zebrafish pou2. The amino acid sequence of the POU domain of pou2 is closely related, but not identical, to that of GP-3.

\section{Structural analysis of zebrafish pou2}

Figure 1 shows the complete nucleotide and the deduced amino acid sequences of pou 2 cDNA. The longest open

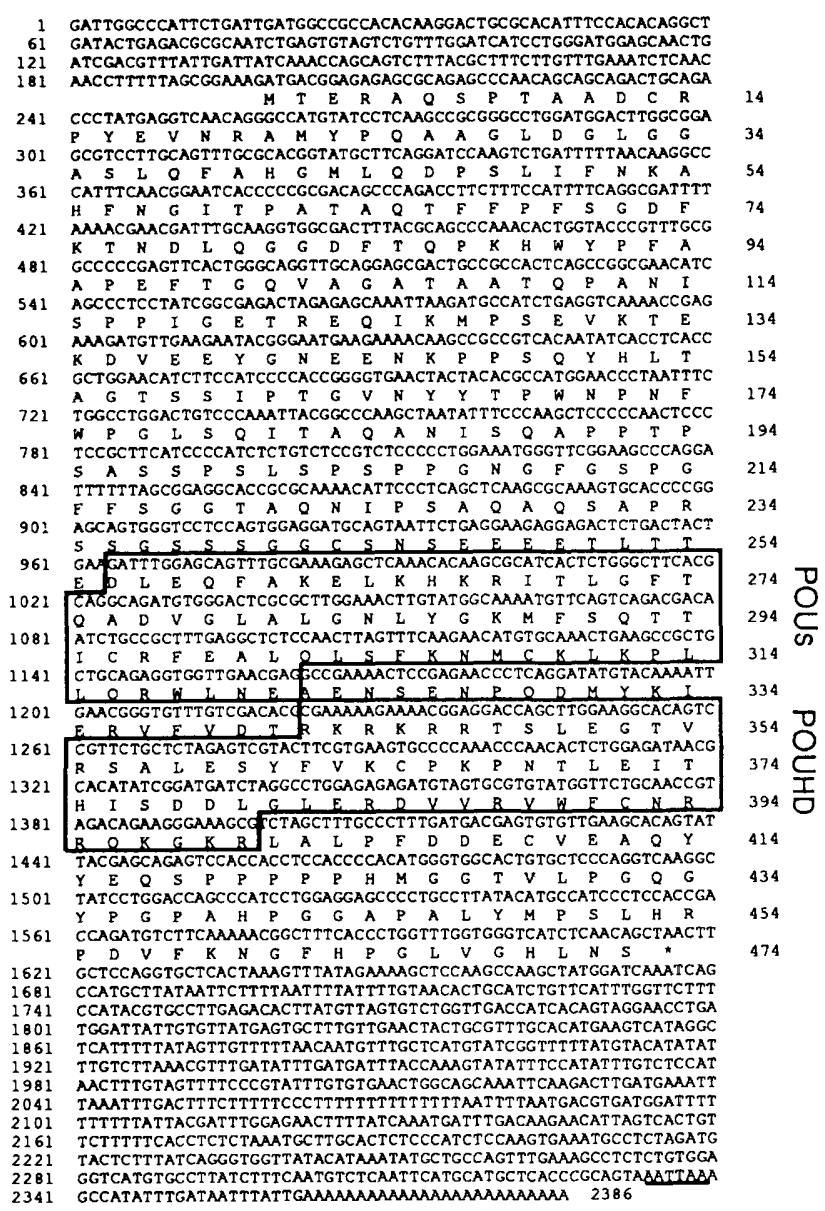

Figure 1. Nucleotide and predicted amino acid sequences of zebrafish pou2. The sequence shown here was derived from those of two separate cDNA clones that were fused at the unique NcoI site (nucleotide position 714). The POU-specific (POUs) and POU homeo domain (POUHD) are boxed. The putative polyadenylation sequence is underlined. 
reading frame predicts a POU domain-containing protein of 472 amino acid residues with a calculated molecular mass of $52 \mathrm{kD}$. The first AUG codon (at position 199), 30 bases after an in-frame stop codon, was denoted the methionine initiator. It is present in the sequence 5'-AAGATGA of the cDNA, which contains an adenine residue, 3 nucleotides upstream from the AUG codon. This nucleotide at such a position was shown to have a dominant effect on the initiation of translation (Kozak 1986). This arrangement suggests that ATG at the position 199-201 could be used as the initiation site for translation. Putative polyadenylation signal (AAUUAA) can be found in the $3^{\prime}$ end, 21 bases upstream of the poly(A) tract. In spite of a 1-base change from the canonical polyadenylation signal hexamer AAUAAA, the hexamer AAUUAA, when located at an appropriate distance from the poly(A) addition site, also can be used as a polyadenylation signal (Birnstiel et al. 1985).

Computer search of the GenBank and EMBL data bases using sequences of Pou2 outside of the POU domain failed to reveal significant similarities to the nucleotide and protein sequences reported previously. The POU domain consists of two highly conserved regions, the POUspecific domain and the POU homeo domain, joined by a linker region of variable lengths and sequences. From analysis of conserved and nonconserved residues, the POU domain family was divided into five classes: class I (Pit-1), class II (Oct-1 and Oct-2), class III (Brn-1, Brn-2, Tst-1, etc), class IV (Brn-3 and unc-86), and class V (Oct3) (Fig. 2). A comparison of the POU domain amino acid sequence of Pou2 with those of other members of the POU domain proteins shows that Pou 2 is closely related to Oct-3: $79 \%$ similarity in the POU-specific domain, $74 \%$ in the POU homeo domain, and $38 \%$ in the linker region (Fig. 2). Pou 2 also shows a high degree of sequence similarity to the class III POU domain protein (Brn-1): $82 \%$ in the POU-specific domain, $68 \%$ in the POU homeo domain, but no homology in the linker region. Recently identified $X$. laevis embryonic POU domain genes, xloct-25 and xloct-91 (Hinkley et al. 1992), also show a similarity to Pou2. However, within a given class, the POU-specific domains have $>85 \%$ similarity,

\footnotetext{
A POU-SPECIFIC DOMAIN zebrafish pou2

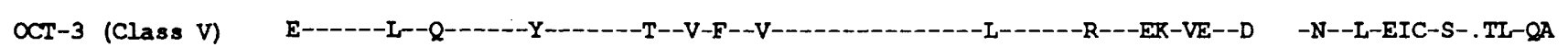
Bm-1 (Class III)

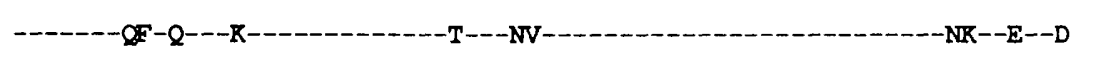
SSTGSPT. .SIDRIAAQG XIOCT-25 XIOCT-91


-ND-I-ELINR-Q-IAQ-

POU-HOMEO DOMAIN

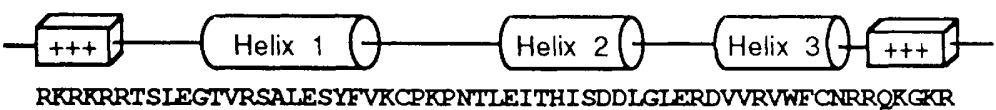

Identity

zebrafish pou2

RRRKRRTSLEGTVRSALESYFVKCPKPNTLEITHISDDLGIERDVVRVWF CNRRQRGRR

$\infty$ (Class $V$ )

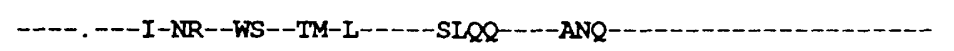

798 in 200

748 in HOMEO

Brn-1 (Class III)

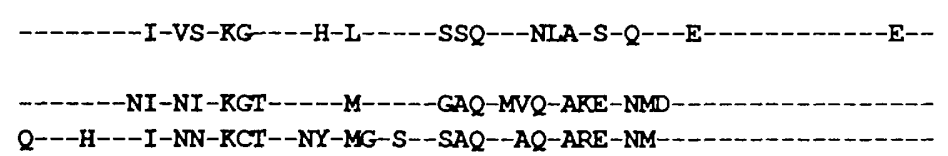

828 in $P O O$

$68 \%$ in HOMEO

XIOCT-25

Q---H---I-NN-RCT--NY-MG-S--SAQ--AQ-ARE-NM-

798 in $\mathrm{POO}$

$66 \%$ in HOMEO

XIOCT-91

788 in $\mathrm{POO}$

$63 \%$ in HOMEO

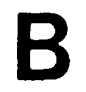

$\begin{array}{lllll}\text { Class I } & \text { (Pit-1) } & 588 \text { in POU } & 498 \text { in HOMEO } \\ \text { Class II } & : \text { (Oct-2) } & 748 \text { in POU } & 568 \text { in HOMEO } \\ \text { Class III } & : \text { (Brn-1) } & 828 \text { in POU } & 688 \text { in HOMEO } \\ \text { Class IV } & \text { (unc-86) } & 608 \text { in POU } & 418 \text { in HOMEO } \\ \text { Class V } & : \text { (Oct-3) } & 798 \text { in POU } & 748 \text { in HOMEO }\end{array}$

Figure 2. (A) Comparisons of the deduced amino acid sequence of the zebrafish Pou2 POU domain with those of other related POU family proteins. The Pou2 sequence is presented at the top, and the basic and helix-forming regions are represented schematically above the sequence. Amino acids are shown in one-letter codes. A dash (-) represents an identical residue, and a dot indicates a gap. (B) Comparisons of the deduced amino acid sequence of the Pou2 POU domain with those of five representative family (class I-V). The numbers indicate percent of identical amino acid residues in POU-specific (POU) or POU homeo domain (HOMEO). Roman numerals show classes of the POU family proteins in accordance with the proposal of He et al. (1989).
} 
and the POU homeo domains have $>75 \%$ similarity. On the basis of the amino acid sequence similarity in both the POU-specific and homeo domains, Pou2 likely represents a new class of POU domain proteins, which is related to both class III and class V. Two zebrafish POU family genes were isolated so far: ZFPOU1 (Matsuzaki et al. 1992), a zebrafish homolog of the mammalian brn-1 (class III); and pou/c] (Johansen et al. 1993). pou[c] also shows a divergent POU domain sequence but no sequence homology with pou2.

\section{Temporal and spatial localization of pou $2 \mathrm{mRNA}$ during embryogenesis}

To analyze the ontogenetic expression pattern of pou2, we performed Northern blot experiments. As seen in Figure 3 , we detected $3.5-\mathrm{kb}$ transcripts during early embryogenesis. The transcripts were maternally expressed. An increase in transcript level is observed at the shield stage, indicating that the zygotic expression starts after midblastula transition. Considerable amounts of transcripts are present by the gastrula stage. When gastrulation is completed $(100 \%$ epiboly), the expression is rapidly down-regulated and no transcripts are detectable 16 hr postfertilization (hpf).

More detailed analysis of expression was performed by in situ hybridization to whole embryos or frozen sections using digoxigenin (DIG)-labeled RNA probes. As expected from Northern blot analysis, expression of pou2 can be visualized at the one-cell stage (Fig. 4A). The

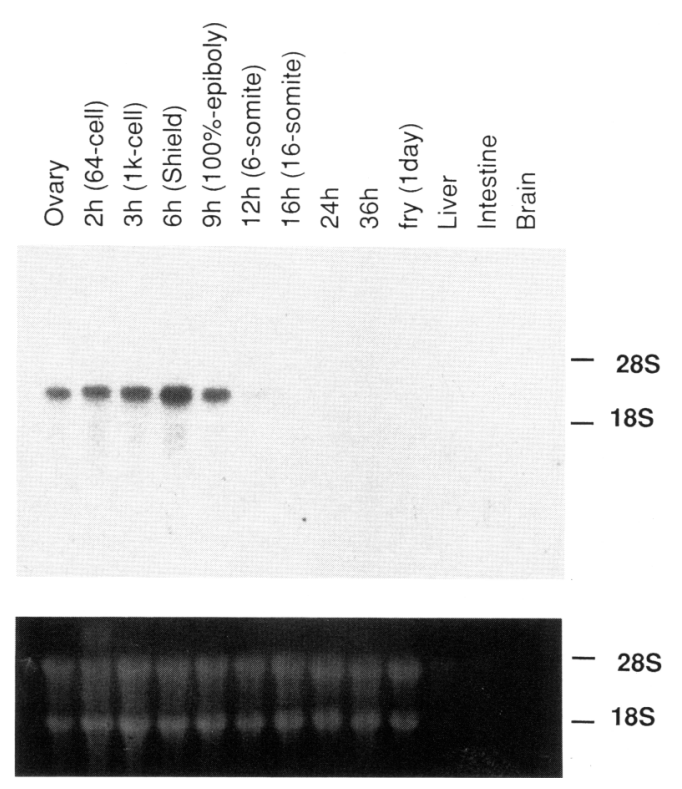

Figure 3. Northern blot analysis of pou2 transcripts in embryos and adult tissues. Ten micrograms of total RNA (adult ovary and embryos of each stage) or $2 \mu \mathrm{g}$ of poly $(\mathrm{A})^{+}$RNA (adult liver, intestine, and brain) was used. The pou2 transcripts are present from the oocyte to the gastrula stage. They are downregulated when gastrulation is completed. So far, no adult tissue has been found positive except for the ovary. (Bottom) Ethidium bromide staining of the filter. transcripts are evenly distributed in all blastomeres until the blastula stage (Fig. 4A); this was confirmed by in situ hybridization to frozen sections of the blastula-stage embryos (data not shown). During gastrulation, involution occurs at or near the blastoderm margin, a movement that folds the blastoderm into two cellular layers, the epiblast and hypoblast (Warga and Kimmel 1990). Whole-mount in situ analysis at this stage demonstrates the expression of pou2 in an entire embryo, but in situ analysis to frozen sections reveals that only the epiblast shows a high level of pou2 expression while the enveloping layer (EVL), yolk syncytial layer (YSL), and newly formed hypoblast do not (Fig. 4B). As gastrulation proceeds, the expression pattern of pou2 changes dramatically; the gene starts to be shut off in most parts of the epiblast except for the dorsal midline and a transverse band in the lateral region, resulting in $\mathrm{T}$-shaped positive areas in whole-mount samples of $100 \%$ epiboly (Fig. 4C).

To define the developmental fate of these positive areas in the epiblast, we compared the expression pattern of pou2 with that of pax $[z f-b]$ gene. It has been demonstrated that the transcripts of pax $[z f-b]$ are already present at the early neurula stage and the positive cells appear as two laterally located transverse stripes in the rostral one-third of the embryo (Krauss et al. 1991) (Fig. 5B). These two positive areas subsequently move toward the midline and form the posterior portion of the midbrain (Krauss et al. 1991) (Fig. 5A). Whole-mount in situ hybridization using both the pou2 and pax $[z f-b]$ antisense probes was carried out. This double hybridization showed that the anterior border of the pou2-positive area overlaps the posterior border of the pax $[z f-b]$-positive area (Fig. 5B), indicating that the transverse band of the pou2-positive area contains at least the future hindbrain region.

pou2 expression in the epiblast becomes weaker during later development and is finally confined to a very restricted area in the tail at the tailbud stage (Fig. 4D). No expression can be seen 24 hpf. We also examined 2and 3-day fries but could not detect expression.

\section{t-pou2: an alternatively spliced product of zebrafish pou2}

During the screening of pou2 cDNA, we obtained one positive clone (clone 2-5) that has an open reading frame encoding a smaller protein. This protein has an amino acid sequence identical to that of Pou2 in the aminoterminal region but has an incomplete POU homeo domain (Fig. 6A). In this clone, 4 nucleotides are missing in the region corresponding to the third helix of the POU homeo domain of Pou2, which results in a frameshift of translation and premature termination of translation. Apart from the 4-base deletion, the nucleotide sequence of clone 2-5 is identical to those of four other independently isolated positive clones. Therefore, clone 2-5 could be an alternatively spliced form of the pou2 gene. We examined this by analyzing the intron-exon structure of the pou2 gene in the region encoding the POU domain. Appropriate oligonucleotide primers corre- 
Figure 4. In situ hybridization analysis showing spatial expression pattern of zebrafish pou2 transcripts during early development. $(A)$ Whole-mount in situ hybridization from one-cell stage to gastrulastage embryos. As the bulk of the oocyte is taken over by the yolk, cell division is limited to a small disk of yolk-free cytoplasm atop the amount of yolk (discoidal cleavage). The blastoderm at the animal pole then begins to extend toward the vegetal pole (epiboly), during which the involution and convergence proceed. The hybridization signal extends to almost all areas of developing embryos. No specific signal is detected in control experiments using a sense probe. The animal pole is at the top in every embryo. (B) In situ hybridization to a frozen section near the dorsal marginal region of an embryo of $80 \%$ epiboly. At this stage, the positive signal is restricted to the epiblast while the enveloping layer (EVL), yolk syncytial layer (YSL) and newly formed hypoblast (*) are negative. $(C)$ Whole-mount in situ hybridization in embryos in which gastrulation has just been completed (100\% epiboly). The expression of pou2 transcripts is reduced in most parts while the restricted areas in the dorsal midline region remain positive, exhibiting a T-shaped positive area. The upper two are lateral views; the lower two are dorsal views. Embryos hybridized with a sense probe are on the left; those with an anti-sense probe are on the right. All embryos are oriented anterior-posterior from left to right. (D) Whole-mount in situ hybridization in 1-somite (1-so), 6-somite (6-so), and 17-somite (17-so) stage embryos and a 24-hr (24-h) embryo. The positive signal is confined to the tip of the tail, and no specific signal is detected after $24 \mathrm{hr}$ of development.

sponding to the amino-terminal boundary of the POUspecific domain and the carboxy-terminal boundary of the POU homeo domain were used to amplify DNA from zebrafish genomic DNA. This PCR generated a $\sim 2.7 \mathrm{~kb}$ DNA fragment, whereas PCR with the same primers using cDNA as a template yielded the expected 500-bp fragment. Subsequent cloning and sequencing of the PCR-generated genomic DNA fragment indicated that there are three introns within the POU domain and that one of them exists in the middle of the third helix of the POU homeo domain (Fig. 6B). Examination of the structure of this small intron revealed the presence of a consensus $5^{\prime}$ splice donor site, a polypyrimidine tract, and two potential consensus $3^{\prime}$ splice acceptor sites 4 nucleotides apart (Fig. $6 \mathrm{C}$ ). These data indicate that clone 2-5 corresponds to the mRNA that is generated using the distal 3' splice site, whereas pou2 cDNA, which is represented by other four clones, corresponds to the mRNA that is generated by the use of the proximal 3' splice site.

We then examined the relative abundance of these transcripts during development. Because the results obtained by RNase protection assay varied greatly from experiment to experiment, probably due to the inability of ribonucleases to recognize quantitatively the small 4-base mismatches under our experimental conditions, we performed quantitative reverse transcriptase-PCR (RT-PCR). cDNAs were synthesized from total RNAs of various developmental stages using a reverse primer that corresponds to the region downstream to the POU domain of pou2 and were used as templates for subsequent PCR amplification. This PCR amplification was expected to yield a 184-bp DNA fragment corresponding to the pou2 mRNA and a 180-bp DNA fragment corresponding to the alternatively spliced form. The conditions for PCR were determined so as to assure a linear amplification (Fig. 7C,D). The amplified products were analyzed by a sequencing gel. As shown in Figure 7A, two amplified fragments of expected sizes were produced at all developmental stages examined, indicating that the alternatively spliced form of pou2 mRNA utilizing the distal $3^{\prime}$ splice site is really expressed. We refer to this alternatively spliced form as $t$ (twin)-pou2. The relative abundance of these transcripts was determined (Fig. 7B). The ratio in amount of $t$-pou2 to pou2 mRNA was $5-10 \%$ before gastrulation, and the ratio increased thereafter to $10-20 \%$. Thus, a single gene produces two mRNAs encoding very similar but probably functionally distinct proteins.

\section{DNA-binding activity}

Most members of the POU domain proteins bind to the conserved octamer sequence (ATTTGCAT) through their POU domains. The protein encoded by the pou2 mRNA possesses a complete POU domain, whereas that encoded by the $t$-pou 2 mRNA lacks the third helix and 


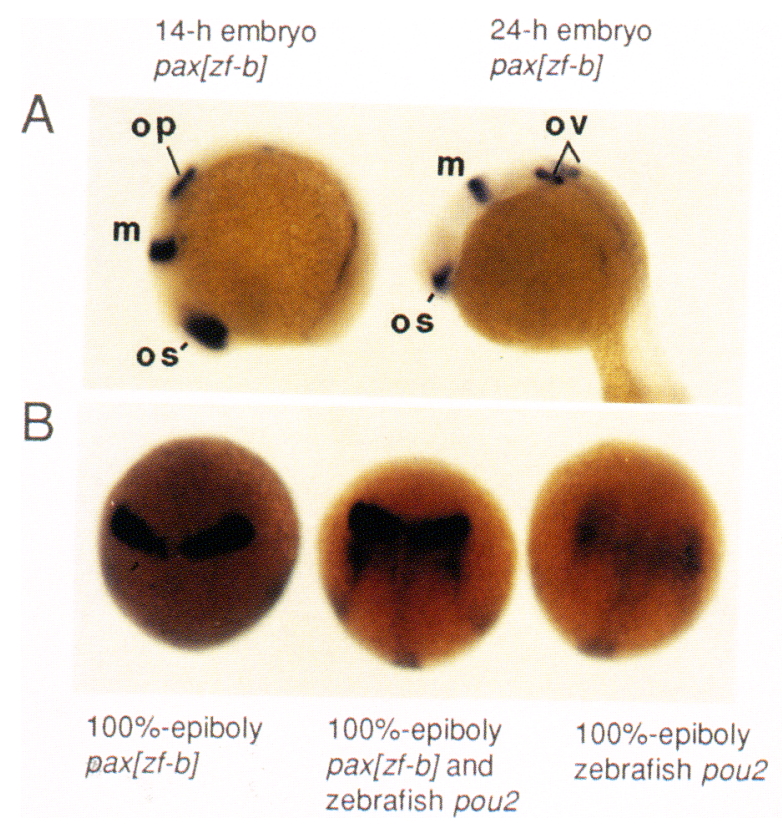

Figure 5. Whole-mount in situ hybridization analysis of pax $[z f-b]$ and pou2 transcripts. (A) In situ hybridization of pax $[z f-b]$ on whole-mount embryos at 14 and $24 \mathrm{hr}$ of development. Lateral views are shown. The embryos are oriented with their anterior ends to the left. The eye stalk (os), posterior part of the midbrain $(\mathrm{m})$, and the otic placode (op) or otic vesicle (ov) are positive. The precise expression pattern has been described by Krauss et al. (1991). (B) In situ hybridization of pax $[z f-b]$, pax $[z f-b]$ and pou2, and pou2 on whole-mount embryos at $10 \mathrm{hr}$ of development ( $100 \%$ epiboly). Dorsal views are shown. The embryos are oriented with the anterior end to the top. When hybridized with the pax $[z f-b]$ probe, positive cells appear in two transeverse bands in the rostral one-third of the embryo. In a double-staining embryo, the posterior border of the pax $[z f-b]$ positive area is overlapped by the anterior border of the pou2positive area.

the 3 ' basic region of the POU homeo domain. As a first step in characterizing the functions of these proteins, we examined whether or not the protein binds to the octamer motif. Full-length RNAs of pou2 and t-pou2 were prepared from the cDNA constructs and used for in vitro translation. The molecular sizes of Pou 2 and $t$-Pou2 proteins were calculated as 63 and $57 \mathrm{kD}$ by SDS-polyacrylamide gel electrophoresis (PAGE), respectively (Fig. 8A). These values are $\sim 10 \mathrm{kD}$ larger than those expected from the deduced amino acid sequences (the expected values are $52 \mathrm{kD}$ for Pou2 and $44 \mathrm{kD}$ for t-Pou2). For a mobilityshift DNA-binding assay, these proteins were incubated with the immunoglobulin $\mathrm{k}$-chain promoter probe containing either the wild-type (wt-kp) or the mutant octamer sequence (mut-kp). As seen in Figure 8B, the Pou2 protein specifically bound to the wild-type but not to the mutant octamer-containing sequence, whereas the $\mathrm{t}$-Pou2 protein did not bind to the wild-type octamer probe. Furthermore, the t-Pou2 protein did not affect the binding of the Pou2 protein to the wild-type octamer probe when they were mixed (data not shown).

\section{Overexpression of pou2 or $\mathrm{t}$-pou2 product}

To examine the roles of the Pou2 and t-Pou2 proteins, we caused an increase in their expression in the embryo by microinjecting synthetic pou2 or $t$-pou2 RNA into fertilized eggs at the one-cell stage. The eggs were then allowed to develop for $12 \mathrm{hr}$ at $28.5^{\circ} \mathrm{C}$, by which time control embryos had reached the three to five somite stage (Fig. 9A). The increase and widespread presence of the injected RNAs at the time of examination were confirmed by whole-mount in situ hybridization (Fig. 9B). An RNase protection assay revealed that the quantity of undegradated injected RNA surviving to the gastrula stage was $\sim 15$-fold excess over the amount of endogenous pou2 mRNA after injection of $0.15 \mu \mathrm{g} / \mu \mathrm{l}$ RNAs at the one-cell stage (Fig. 10A). In this assay, the presence of excess probe over injected RNAs was confirmed by a linear decrease in the intensity of protected fragments with decreasing amount of the RNA used (Fig. 10B,C). To test in vivo translation of the injected RNAs under our experimental conditions, synthetic RNA encoding Esherichia coli $\beta$-galactosidase was injected at the onecell stage alone or along with pou2 RNA. The presence of $\beta$-galactosidase enzyme was visualized by staining the injected embryos with X-gal. The X-gal staining was positive in an entire body of all injected embryos from the blastula stage up to $24 \mathrm{hpf}$ (Fig. 9C). These injected embryos developed normally.

As summarized in Table 1, most embryos that developed from the eggs injected with pou2 RNA did not show any developmental defect (Fig. 9A). In contrast, injection of $t$-pou2 RNA greatly affected the development: Most injected embryos showed marked developmental retardation or arrest before completion of gastrulation (Table 1; Fig. 9A). The embryos injected with both pou2 and $t$-pou2 RNAs also showed a high frequency of abnormal development (Table 1). A disturbance in normal development becomes evident at early blastula stage $(3 \mathrm{hr})$, and most embryos failed to complete gastrulation even after $12 \mathrm{hpf}$. The surface of the blastoderm in these affected embryos appears rough during epiboly, probably because of a decrease in cell adhesiveness (Fig. 11A-D), and the epiboly proceeds more slowly than that in the pou2-injected embryos. Histological sections of these embryos at the stage of $50-60 \%$ epiboly showed that although the hypoblast involution did occur at the blastoderm margin in t-pou2-injected embryos, the structure of the hypoblast was disturbed as compared with that in the pou2-injected embryos (Fig. 11F,H). It has been demonstrated that in the blastoderm margin, the zebrafish $T$ gene is activated during normal development (SchulteMerker et al. 1992). We examined the expression of $T$ in RNA-injected embryos. The $T$ gene is normally expressed in pou2-injected embryos. In constrast, its expression is greatly reduced in $t$-pou2-injected embryos at all stages examined (Fig. 11E,G).

Some affected embryos were allowed to develop for another $12 \mathrm{hr}$, and most of them $(>90 \%)$ died before they reached the neurula stage. Besides E. coli lacZ RNA, we carried out injection of ZFPOU1 RNA (Matsuzaki et al. 
A

pou2 (472 aa)

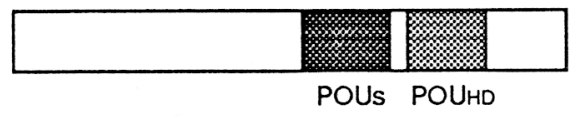

t-pou2 (399 aa)

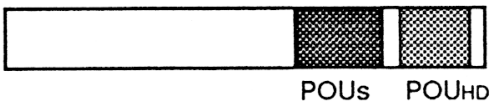

B

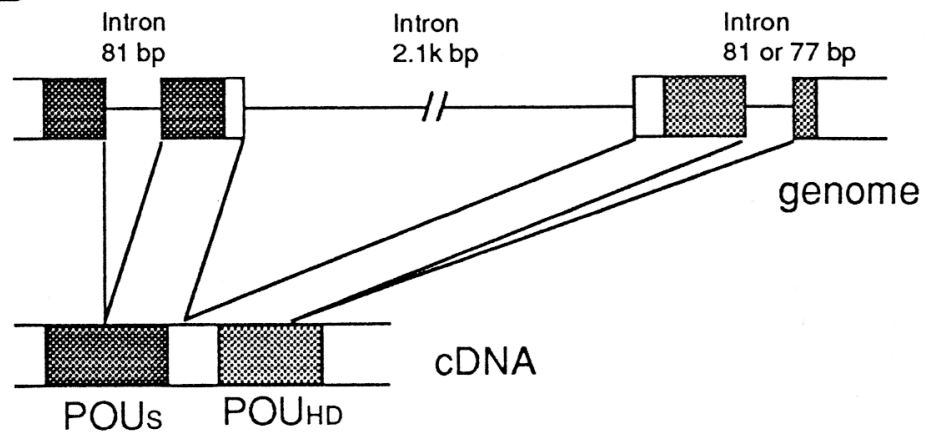

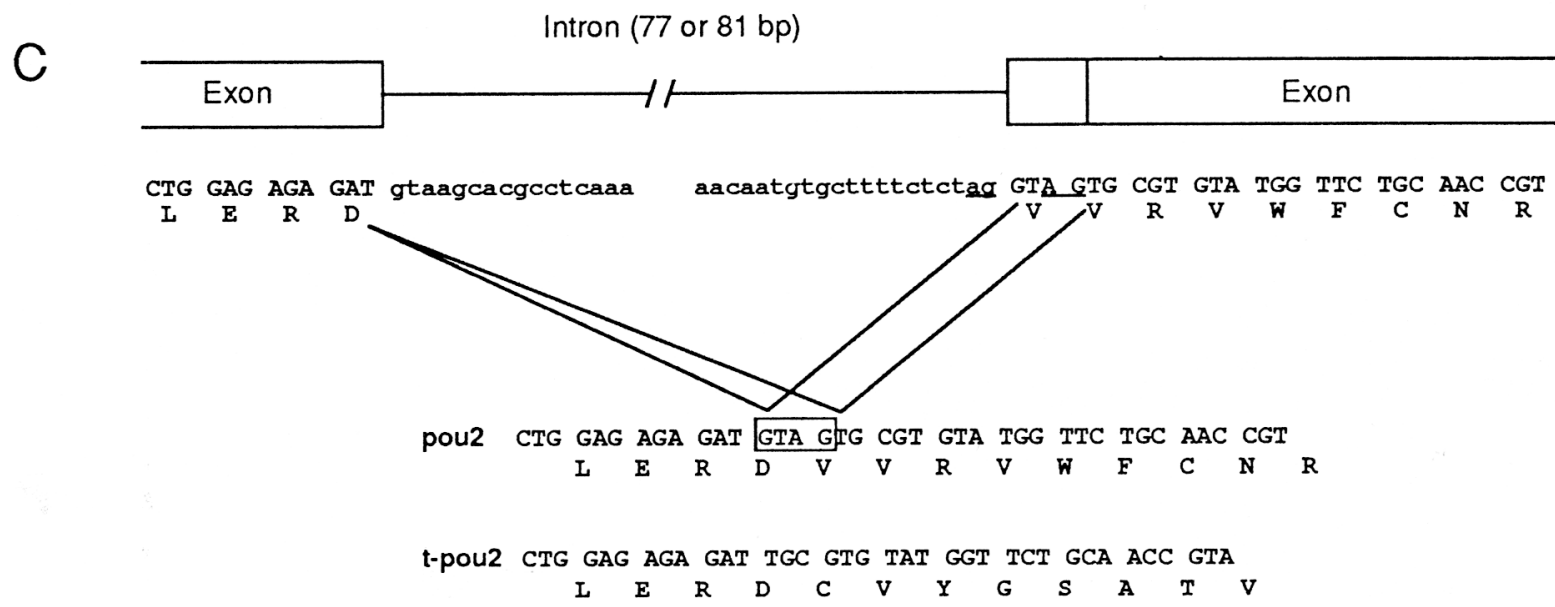

Figure 6. Alternatively spliced products from the pou2 gene. $(A)$ Schemes of the two putative proteins produced from the pou2 gene. The two proteins are identical from the amino terminus to the POU-specific domain. $t$-Pou2 lacks the third helix and basic regions of the POU homeo domain. (B) Structure of the pou2 gene encompassing the POU domain. There are four exons divided by three introns in the POU domain region. $(C)$ The intron-exon boundaries are shown for the pou 2 gene in the carboxy-terminal region of the POU homeo domain. This small intron (shown in part) contains a consensus donor site and two potential $3^{\prime}$ acceptor sites (underlined). This genome structure can generate two spliced products, as depicted: pou 2 and $t$-pou2.

1992|, but no marked effects on early development were observed (data not shown).

\section{Discussion}

\section{Structure and expression of zebrafish pou2}

We have determined the full-length coding sequence of a novel POU domain gene, pou2, and examined in detail its spatiotemporal expression pattern. There are no significant stretches of homology among other POU domain genes outside the POU domain. The amino acid sequence of Pou2 POU domain is related most closely to that of the murine POU domain protein Oct-3. However, the percent identity to the Oct-3 protein is not sufficient to place Pou2 in the same POU domain class (i.e., class V). Recently, several novel POU domain proteins have been described (Frank and Harland 1992; Hinkley et al. 1992; Whitfield et al. 1993), which also have diverged POU domain sequences and are related most closely to, but are not the members of, class V (Oct-3). All of these genes are expressed during early development and are thought to play important roles in the determination of cell fate and the regulation of cell proliferation.

In addition to the structural similarity to oct-3, the expression pattern of the pou2 gene resembles that of oct-3 during mouse development (for review, see Schöler 1991). Initially, oct-3 transcripts are distributed uniformly in mouse oocytes and early blastocysts. oct-3 expression subsequently declines in trophectoderm-derived cells and becomes progressively restricted first to the inner cell mass and then to the primitive ectoderm. By day 11 , oct- 3 transcripts are present only in primordial germ cells and oct-3 expression in the adult is restricted to gonadal cells. Similarly, pou2 is maternally expressed, and the transcripts are present from the onecell stage to the gastrula stage. The amount of the transcripts increased and reached the peak level at the shield stage (early gastrula), which is contributed by zygotic expression after midblastula transition. In situ hybridization analyses revealed that the transcripts are present in all blastomeres until the midblastula stage, and thereafter the expression becomes restricted. Both the YSL 
A
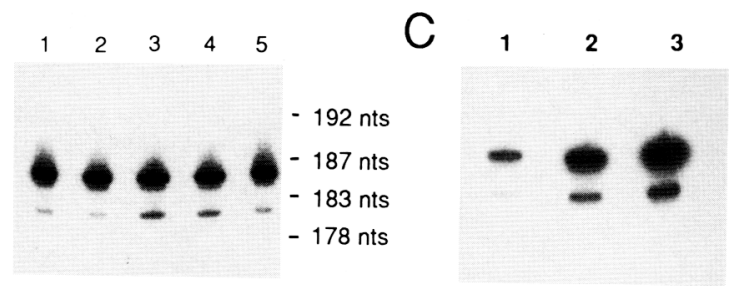

B
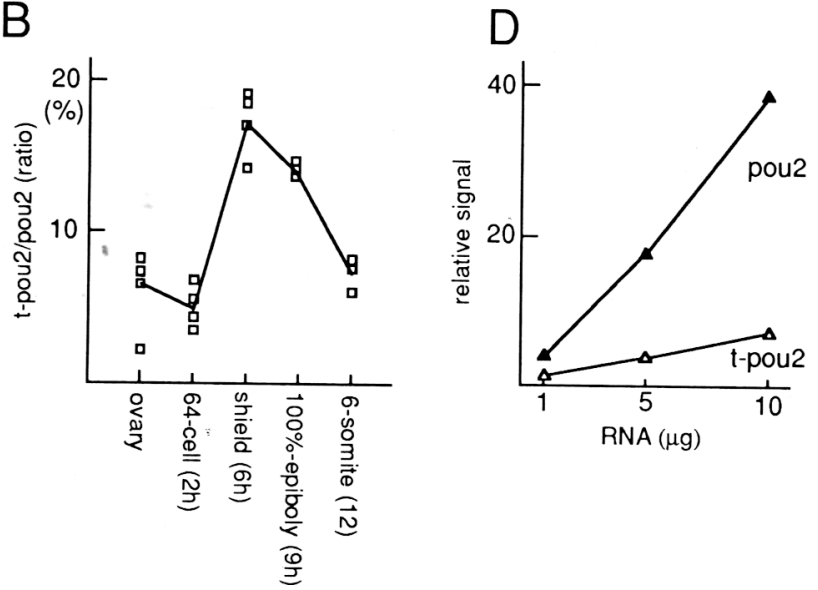

Figure 7. Relative abundance of pou2 and t-pou2 transcripts. (A) Quantitative RT-PCR ( 20 cycles) was performed using total RNAs prepared at various embryonic stages. (Lane 1) Ovary; (lane 2) 64-cell stage; (lane 3) shield stage; (lane 4) 100\% epiboly; (lane 5) 6-somite stage. cDNA was primed by a reverse primer that corresponds to downstream of the POU homeo domain and is used as a template for PCR amplification. The primers used in the PCR covered the third helix structure of the POU homeo domain, and the upstream primer was end-labeled with $\left[\gamma^{-32}\right.$ P]ATP. Approximately the same amount of the radioactivity from the amplified products was applied to a sequencing gel. Under these conditions, the 184-nucleotide fragment represents pou2 cDNA while the 180-nucleotide fragment represents $t$-pou2 cDNA. $(B)$ The relative abundance of these two products was determined by measuring the radioactivity in each band with a Fujix BAS2000 Bio-imaging analyzer. The plot represents the proportion of $t$-pou $2 \mathrm{cDNA}$ to pou $2 \mathrm{cDNA}$, and three to four independent experiments were performed at each stage. $(C)$ To confim quantitative amplification, 1 (lane 1), 5 (lane 2), and 10 $\mu \mathrm{g}$ (lane 3) of total RNA from the shield-stage embryos were used for cDNA systhesis, followed by PCR amplification of 20 cycles. $(D)$ The relative signal in $C$ was determined and plotted against the amount of RNA used.

and the EVL cells first lose the expression, and subsequently the expression in the hypoblast is down-regulated. The decrease in Pou2 expression seems to be correlated with the loss of pluripotency. From the one-cell stage to the midblastula stage, embryonic blastomeres in zebrafish embryos are believed to be pluripotent or not yet committed to express a particular fate. The YSL and the EVL cells, characterized as extraembryonic, first become tissue-restricted lineages. This was shown by labeling with lineage tracing molecules (Kimmel and Law 1985), transplantation experiments (Ho 1992), and by observing similarities in cell cycle lengths (Kane et al. 1992). When gastrulation starts, the deep cells near the margin involute to form the hypoblast, which is committed to giving rise to the mesoderm and endoderm. The noninvoluting deep cells form the outer epiblast. pou2 expression remains high in the epiblast during gastrulation. After the inductive interaction with the mesodermal tissues, the epiblast finally gives rise to both the central nervous system and epidermal tissues. The down-regulation of pou2 expression in the epiblast also seems to be correlated with these events. After $16 \mathrm{hr}$ of development, pou2 transcripts are undetectable in any embryonic tissues. This characteristic expression pattern strongly suggests that Pou2 is required to maintain a highly undifferentiated state.

The germ-cell lineage of zebrafish has not yet been described and the expression of pou2 in this lineage remains to be elucidated. In the adult, pou2 is found in the ovary. The identity of the cells expressing pou2 in the ovary was not determined here.

At the early neurula stage $(100 \%$ epiboly) the expression of pou2 is confined to a very restricted area in the dorsal region of the epiblast ( $\mathrm{T}$-shaped positive area in Fig. $4 \mathrm{C}$. At this stage, the transcripts of pax $[z f-b]$, which

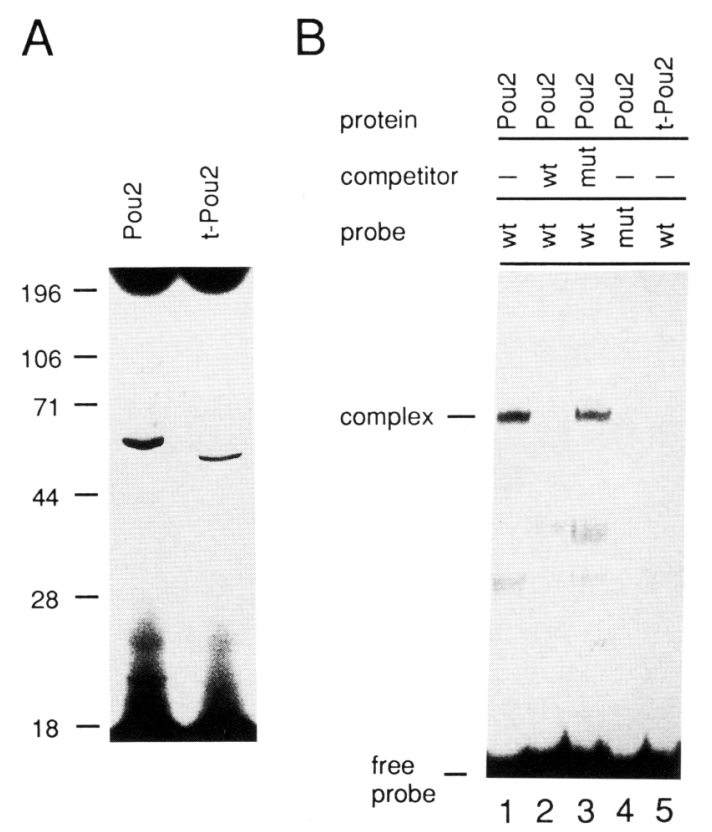

Figure 8. Octamer-binding activity of in vitro-synthesized Pou2 proteins. $(A)$ SDS-PAGE analysis of in vitro-synthesized Pou 2 and $t$-Pou2 proteins. The capped RNA was prepared from the pBluescript vector containing either pou2 or $t$-pou2 cDNA and used for in vitro translation in the presence of $\left[{ }^{35} \mathrm{~S}\right] \mathrm{methio-}$ nine. The protein products were analyzed by $10 \%$ SDS-PAGE. Sizes of molecular mass markers (in kD) are indicated at left. $(B)$ Mobility-shift DNA-binding assay of Pou2 and t-Pou2 proteins. Proteins synthesized in vitro were subjected to the assays using either ${ }^{32} \mathrm{P}$-labeled wild-type (wt) or mutant (mut) $\kappa$-chain promoter $(\mathrm{kp})$ probe. In some assays, 100 -fold excess of unlabeled oligonucleotides was added as competitor. (Lanes 1-4) Protein synthesized from pou2 sense RNA; (lane 5) protein synthesized from $t$-pou2 sense RNA. The Pou2 products specifically bind to the octamer-sequence while the t-Pou2 products do not. 


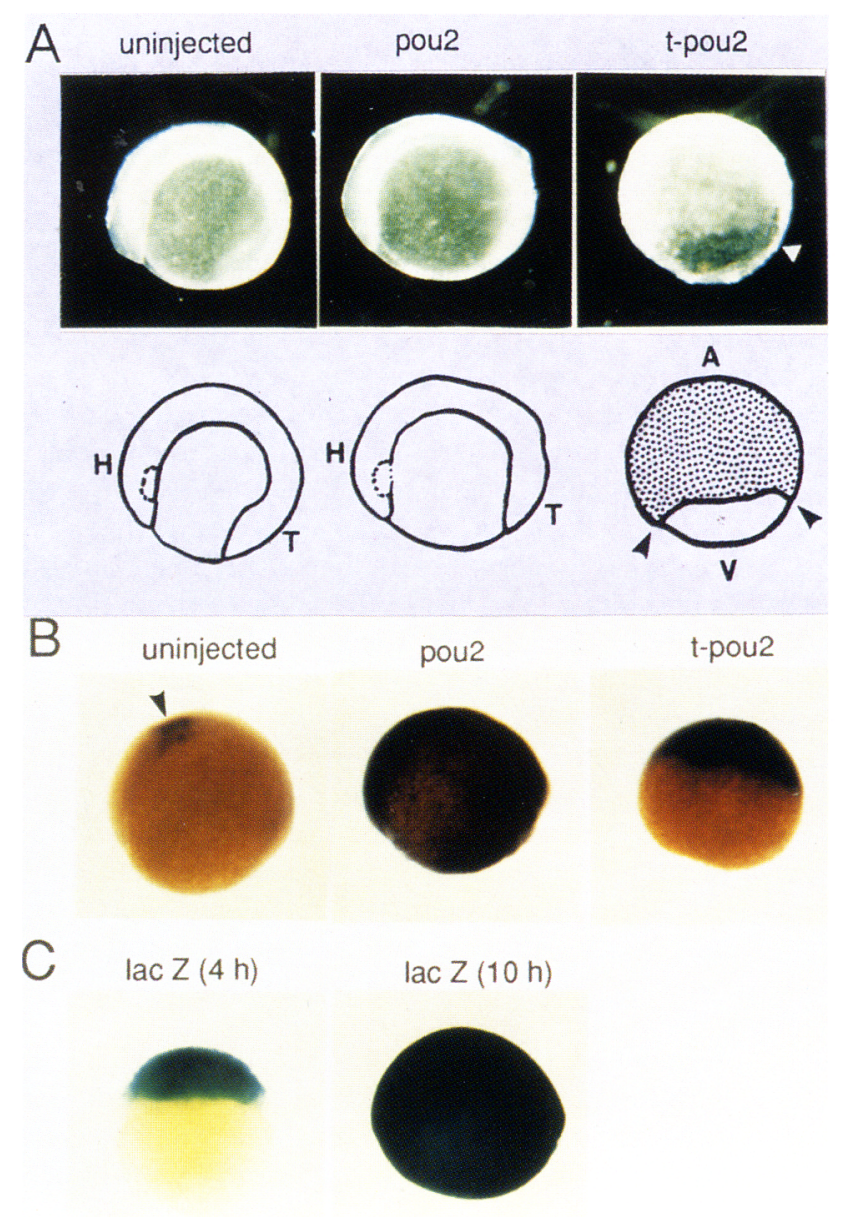

is involved in the formation of the midbrain-hindbrain junction (Krauss et al. 1992), are detected (Krauss et al. 1991). This indicates that the neural epithelial cells are commited to subdivisions as early as the early neurula stage. Comparison of the staining pattern of pax $[z f-b]$ with that of pou2 indicated that the latter was expressed in the presumptive hindbrain region, suggesting an involvement of Pou2 in the early specification of the neural epithelium. The staining in the dorsal midline of the epiblast disappears soon after the end of gastrulation, and the future fate of this area may be the ventral portion of the neural tube.

\section{Alternative splicing and its role in early embryogenesis}

The generation of two proteins, Pou2 and t-Pou2, as a consequence of alternative splicing events from the same genomic locus was revealed in this study. $t$-Pou2 has an amino acid sequence identical to that of Pou2 from the amino terminus to the POU-specific domain but has an incomplete POU homeo domain where the third helix structure and the $3^{\prime}$ basic region are missing. These regions are highly conserved among POU domain proteins and are believed to be indispensable for their
Figure 9. Effect of injection of pou2 and t-pou2 RNAs on development of zebrafish embryos. $(A)$ External appearance of the embryos $12 \mathrm{hr}$ after injection. pou2 or t-pou2 RNAs were injected into embryos at the one-cell stage, and the embryos were allowed to develop for $12 \mathrm{hr}$. After $12 \mathrm{hr}$ of development, a control embryo (uninjected) reaches the neurula stage. Photographs labeled uninjected and pou2 show embryos that are oriented anterior-posterior from left to right; those labeled t-pou2 show animal pole at the top. The line drawing beneath the photograph outlines the embryo $[(\mathrm{H})$ head; $(\mathrm{T})$ tail; (A) animal pole; (V) vegetal pole]. The embryo injected with pou2 RNAs develops normally and reaches the early neurula stage. In contrast, the embryo injected with $t$-pou2 RNAs fails to complete gastrulation even after $12 \mathrm{hr}$ of incubation; the area around the vegetal pole looks transparent, indicating that the periphery of the blastoderm does not reach the vegetal pole. Arrowheads in the line drawing indicate blastoderm margin. $(B)$ Whole-mount in situ hybridizations in RNA-injected embryos (12 hr postfertilization) using an anti-sense RNA pou 2 probe. The orientation of the embryos is the same as that in $A$. In control, the endogenous pou 2 transcripts were found in a restricted dorsal region (arrowhead). In the pou2 RNA-injected embryo (pou2), the positive signal is distributed in an entire body, which confirms the widespread presence of injected pou2 RNAs. However, the injected embryo seems to develop normally. In the $t$-pou2 RNAinjected embryo (t-pou2) in which the development stops at $50 \%$ epiboly, the positive signal is confined to the blastoderm. $(C)$ Whole-mount staining of $\beta$-galactosidase activity in the embryos injected with $0.15 \mu \mathrm{g} / \mu \mathrm{l}$ of lacZ RNA. The activity was detected in the entire blastoderm $4 \mathrm{hr}$ after injection $(4 \mathrm{~h})$ and in a whole body $10 \mathrm{hr}$ after injection $(10 \mathrm{~h})$. The orientation of the embryos in $4 \mathrm{~h}$ and $10 \mathrm{~h}$ is the same as that in $A$ ( $\mathrm{t}$-pou2 and pou2, respectively). Note that the embryos injected with $l a c Z$ RNA develop normally.

regulatory functions. For example, Li et al. (1990) demonstrated a point mutation (Trp $\rightarrow$ Cys) of an invariant residue within the third helix of the POU homeo domain of the pit-1 gene in the Snell dwarf mutant mouse; this mutated gene generates the nonfunctional Pit-1 protein, which abolishes the expression of growth hormones in the pituitary gland, leading to a dwarf phenotype. A point mutation in the $3^{\prime}$ basic region in the POU homeo domain of the pit-1 gene was also found in a patient with combined pituitary hormone deficiency (Radovick et al. 1992). It is therefore unlikely that the t-Pou2 protein functions as a transcription factor by itself. This was supported by the result obtained in our gel retardation assay that $t$-Pou2 did not bind to the wild-type octamer probe while Pou 2 did. The gel retardation assay also revealed that $\mathrm{t}$-Pou2 did not abolish the DNA-binding activity of Pou2 at least under in vitro conditions. So, what function does t-Pou2 have? Is it a nonfunctional protein produced by a splicing error? We addressed this question by increasing the expression of these products in the embryo by microinjection of synthetic pou2 or $t$-pou2 RNAs into fertilized eggs. Surprisingly, the overexpression of Pou2 did not cause any obvious effect on development. It was expected from the expression pattern that 


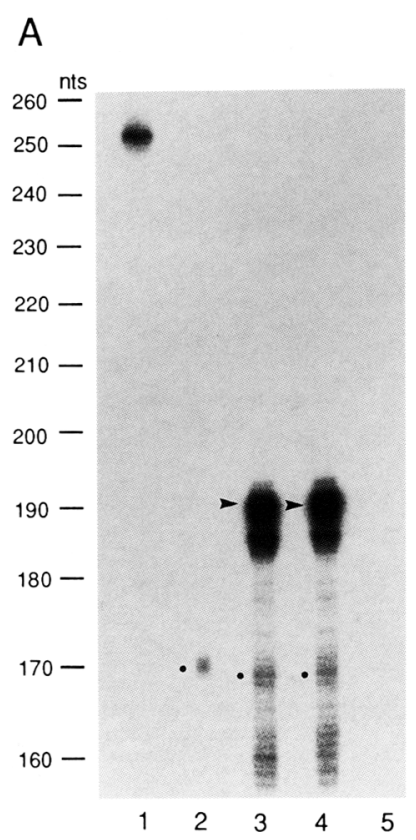

B

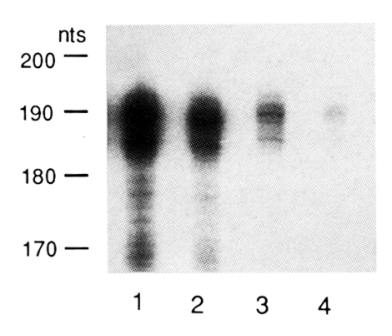

C

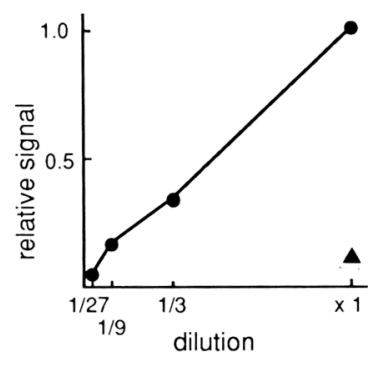

Figure 10. RNase protection experiments to estimate endogenous and injected pou2 RNAs. (A) RNA samples isolated from uninjected (lane 2), pou2-injected (lane 3) and t-pou2-injected (lane 4) embryos, and yeast tRNA (lane 5) were hybridized to a 245-base-long uniformly labeled antisense RNA probe (lane 1) and subjected to digestion with RNases. RNase-resistant fragments were separated on a sequencing gel. Incorporation of a short plasmid polylinker sequence in the synthetic transcripts creates a size difference between the probe lengths protected by the injected (187 bases indicated by arrowheads in lanes 3 and 4 ) and endogenous pou2 (171 bases indicated by dots in lanes 2-4) mRNAs (see Materials and methods). All embryos were collected at $8 \mathrm{hpf}$, and the concentration of RNA solution injected was $0.15 \mu \mathrm{g} / \mu \mathrm{l}$. The relative abundance of endogenous and injected RNAs was measured $(C)$. Molecular size determined by DNA sequence reaction is indicated at left. The protected fragment is slightly larger than expected, because of a difference in mobility between DNA and RNA fragments (Sambrook et al. 1989). (B) To confirm quantitative protection, the RNA samples from the pou2-injected embryos were diluted $1 \times($ lane 1$), 1 / 3 \times$ (lane 2), $1 / 9 \times($ lane 3$)$, and $1 / 27 \times$ (lane 4 ) and were hybridized to the probe. $(C)$ The radioactivity of undegradated fragment was measured and plotted $(0) ;(\mathbf{\Lambda})$ a relative signal of the endogenous pou 2 mRNA.

the overexpression of Pou2 products would keep the blastomeres multipotential and inhibit the cell commitment event. One possible explanation why this did not happen is that Pou2 requires other factors to activate target genes and the expression of these factors is also developmentally regulated (i.e., shut down at the neurula stage). To examine the role of Pou2 in vivo, we will need to suppress its function by an injection of antisense nucleotides or a specific antibody. The overexpression of $\mathrm{t}$-Pou2, on the other hand, caused strong developmental retardation or arrest in the injected embryos before completion of gastrulation. In the affected embryos the involution and the formation of hypoblast was greatly per- turbed at the blastoderm margin. It was also found that overexpression of $t$-Pou 2 products greatly reduced the expression of zebrafish $T$ gene. In normal development the zebrafish $T$ gene is activated before and during gastrulation in cells of the entire blastoderm margin (the germ ring/ including the epiblast, hypoblast, and EVL (Schulte-Merker et al. 1992). Analysis of the mutant mouse $(T / T)$ and the overexpession experiment in Xenopus clearly demonstrated that the $T$ gene is required cell autonomously for mesoderm formation (Herrmann et al. 1990; Cunliffe and Smith 1992). Thus, although the first sign of defects was observed as early as the blastula stage, when the $T$ gene is not activated yet (Schulte-Merker et al. 1992), a disturbance in the formation of hypoblast could be a major defect in t-pou2-injected embryos, which will lead to a failure in the development of mesodermal and endodermal derivatives. Because the pou2 gene is down-regulated in the hypoblast during normal development, the ectopic expression of t-Pou2 may cause inhibitory effects on the hypoblast formation. At present, there is no evidence as to whether Pou2 or $\mathrm{t}$-Pou2 is directly involved in the regulation of the $T$ gene, and it is worth noting that the epiblast near or at the blastoderm margin expresses both the pou2 and the $T$ genes (Schulte-Merker et al. 1992). Taken together, these pieces of information suggest that $\mathrm{t}$-Pou2, which is a non-DNA-binding protein, could have a specific role in early embryogenesis, especially in the process of gastrulation.

There have been examples of the generation of proteins with distinct functions from a single POU domain gene by alternative splicing, for example, murine Oct-2 (Stoykova et al. 1992) and Drosophila I-POU. I-POU, a POU domain protein that lacks two conserved basic amino acids of the POU homeo domain, is coexpressed in the developing Drosophila nervous system with a second POU domain transcription factor, Cf1-a. I-POU does not bind to DNA because of its incomplete POU homeo domain but forms a POU domain-mediated heterodimer with Cfl-a, inhibiting its ability to bind and activate the target gene (Treacy et al. 1991). A twin of I-POU, an alternatively spliced transcript of the $I$-POU gene, was reported and it encodes a protein containing the two basic amino acid residues absent in I-POU. The twin of I-POU is incapable of dimerizing with Cfl-a but can act as a positive transcription factor on targets distinct from those regulated by Cfl-a (Treacy et al. 1992). Interestingly, the differential splicing scheme of the pou2 gene resembles that of $I-P O U$; the two types of alternatively spliced transcripts of I-POU are generated by choosing one of the two $3^{\prime}$ splice acceptor sites 6 bases apart. At present, we have no evidence indicating that Pou2 or $\mathrm{t}$-Pou2 forms heteromeric complexes with other POU domain proteins, although the POU-specific domain and the amino terminus of the POU homeo domain remain intact in $\mathrm{t}$-Pou2, which required for specific protein-protein interactions (Ingraham et al. 1990; Treacy et al. 1992). Nonetheless, it seems reasonable to speculate that by heteromeric interactions with other transcription factors (probably another POU domain protein), t-Pou2 
Table 1. Defects produced in embryos injected with pou2 and t-pou2 RNAs

\begin{tabular}{|c|c|c|c|c|c|}
\hline \multirow[b]{2}{*}{$\begin{array}{l}\text { RNA } \\
\text { injected }\end{array}$} & \multirow[b]{2}{*}{$\begin{array}{l}\text { Conc. of RNA } \\
\text { injected }(\mu \mathrm{g} / \mu \mathrm{l})\end{array}$} & \multicolumn{3}{|c|}{ Embryos with phenotype $(\%)^{b}$} & \multirow[b]{2}{*}{$\begin{array}{l}\text { Total } \\
\text { number }\end{array}$} \\
\hline & & $\begin{array}{l}\text { normal }^{\mathrm{c}} \\
\text { development }\end{array}$ & $\begin{array}{l}\text { developmental }{ }^{\mathrm{d}} \text { arrest } \\
\text { at or before blastula stage }\end{array}$ & $\begin{array}{l}\text { developmental }{ }^{\mathrm{e}} \text { retardation or } \\
\text { arrest at the gastrula stage }\end{array}$ & \\
\hline pou2 & 0.3 & 72 & 18 & 10 & 145 \\
\hline t-pou2 & $\begin{array}{l}0.05 \\
0.15 \\
0.3\end{array}$ & $\begin{array}{l}38 \\
18 \\
13\end{array}$ & $\begin{array}{l}25 \\
27 \\
40\end{array}$ & $\begin{array}{l}36 \\
55 \\
47\end{array}$ & $\begin{array}{r}91 \\
137 \\
158\end{array}$ \\
\hline $\begin{array}{c}\text { pou }^{\mathrm{f}} \\
+ \\
t-\text { pou2 }\end{array}$ & $\begin{array}{c}0.15 \\
+ \\
0.15\end{array}$ & 27 & 37 & 37 & 112 \\
\hline $\begin{array}{l}\text { DW } \\
\text { Uninjected }\end{array}$ & - & $\begin{array}{l}80 \\
88\end{array}$ & $\begin{array}{r}12 \\
7\end{array}$ & $\begin{array}{l}8 \\
5\end{array}$ & $\begin{array}{l}117 \\
200\end{array}$ \\
\hline
\end{tabular}

The RNAs were injected into embryos at the one-cell stage and the embryos were allowed to develop to $12 \mathrm{hr}$ postfertilization. Both RNA- and DW-injected embryos $(2-5 \%)$ died at the molura stage. The results from two to five independent experiments are shown. ${ }^{a} \mathrm{About} 300 \mathrm{pl}$ of RNA solution was injected into each embryo.

bBased on external appearance.

'Embryos that reached the three to five somite (neurula) stage.

eEmbryos that failed to complete gastrulation.

${ }^{\mathrm{d}}$ Embryos that stopped their development before the blastula stage.

'The mixture of pou2 and $t$-pou2 RNAs $(1.5 \mu \mathrm{g} / \mu \mathrm{l}$ each $)$ were injected.

could be involved in the negative regulation of a set of gene activities required for further development. The disappearance of $t$-Pou 2 before the neurula stage may be prerequisite for later development. In fact, generation of functionally distinct transcription factors from a single gene may prove to be a commonly used mechanism. In many cases, transcription down-regulators can heterodimerize with activators, thereby reducing either their DNA-binding affinity or their ability to activate transcription (for review, see Foulkes and Sassone-Corsi 1992).

We have also shown that the pou2 mRNA was preferentially transcribed from the pou2 gene and that the ratio of $t$-pou2 to pou2 mRNA varied among developmental stages. This is probably the result of a different stability between them or a preferential splicing machinery, such as Drosophila Sex lethal protein, which regulates the splicing pattern of the genes below in the hierarchy

Figure 11. Phenotype caused by injection of t-pou2 RNA. $(A-D)$ Nomarski view of RNA-injected embryos. (A) An embryo injected with pou2 RNA $(0.15 \mu \mathrm{g} / \mu \mathrm{l}) 6 \mathrm{hr}$ after injection; $(B)$ the higher magnification of $A_{;}(C)$ an embryo injected with $t$-pou2 RNA $\{0.15 \mu \mathrm{g} / \mu \mathrm{l}) 12 \mathrm{hr}$ after injection; $(D)$ the higher magnification of $C$. Arrowheads in $A$ and $C$ indicate the blastoderm margin. Asterisks in $B$ and $D$ indicate the embryonic shield. The $t$-pou2-injected embryos show developmental retardation, and the surface of these embryos appears rough as compared with that of the pou2-injected embryos. At higher magnification, it is observed that some blastomeres are detached from the surface (arrowheads in $D, E, G$ ) Whole-mount in situ hybridization of zebrafish $T .(E)$ an embryo injected with pou2 RNA $(0.15 \mu \mathrm{g} / \mu \mathrm{l}) 6 \mathrm{hr}$ after injection; $(G)$ an embryo injected with $t$-pou2 RNA 10.15
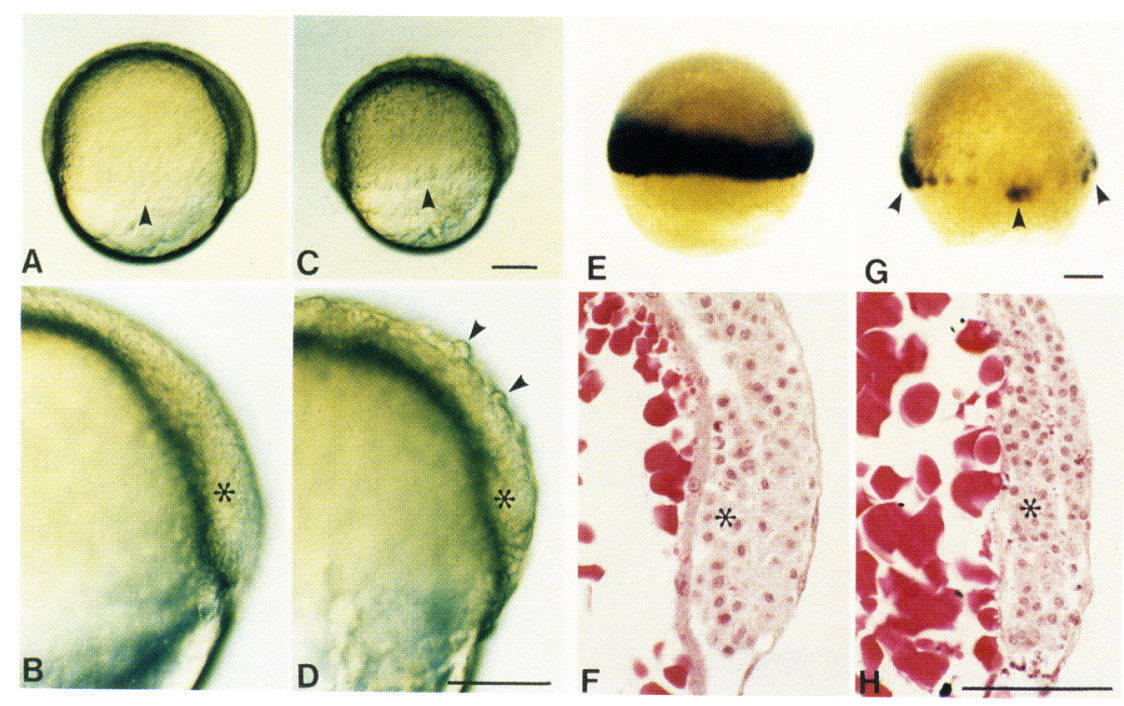
$\mu \mathrm{g} / \mu \mathrm{l}) 12 \mathrm{hr}$ after injection. Arrowheads indicate the blastoderm margin. $(F, H)$ Histology of the blastoderm margin. $(F)$ An embryo injected with pou2 RNA $(0.15 \mu \mathrm{g} / \mu \mathrm{l}) 6 \mathrm{hr}$ after injection; $(H)$ an embryo injected with $t$-pou2 RNA $(0.15 \mu \mathrm{g} / \mu \mathrm{l}) 12 \mathrm{hr}$ after injection. Asterisks $\left({ }^{*}\right)$ indicate the newly formed hypoblastic layer. All scale bars, $100 \mu \mathrm{m}$. 
of sex determination (Baker 1989). In the overexpression experiments, the addition of pou2 mRNA to $t$-pou2 mRNA at the ratio of 1:1 did not abolish the effect of $\mathrm{t}$-Pou2 overexpression. Because the ratio of two products translated in injected embryos cannot be determined precisely, we cannot exclude the possibility that in normal development, the proportion of t-Pou2 to Pou2 may be important in determining cell fate. Nor can we distinguish by in situ hybridization the transcripts for Pou2 from those for $t$-Pou2 because of the small 4-base difference between them. Further study will be needed to localize these two products in the embryos by an antibody specific to each protein.

\section{Conclusion}

Temporal and spatial expression patterns are consistent with the idea that the Pou2 and $t$-Pou2 proteins are involved in early development of zebrafish embryos, such as in the proliferation of blastomeres in undetermined state at the blastula stage and/or the early cell commitment event at the gastrula stage. The effects of overexpression on development suggest that through proteinprotein interactions, pou2 gene products may serve as regulatory proteins in early embryogenesis. Further research should focus on the interaction of Pou2 products with other regulatory proteins in early zebrafish development.

\section{Materials and methods \\ Isolation and characterization of POU domain- containing cDNA clones}

To isolate POU domain-containing cDNA clones of zebrafish, we employed the PCR method. Two 26-mer oligonucleotides, POU1 (TTGGGGTACACCCAGGCCGACGTGGG) and POU2r (CAGAACCATACTCGAACCACATCCTT), were synthesized on the basis of the amino acid sequences of the aminoand carboxy-terminal portions of the Oct-3 POU domain /Okamoto et al. 1990), LGYTQADVG and KDVVRVWFC, respectively. These primers were designed to cover both the POUspecific domain and the POU homeo domain. Thirty cycles of PCR amplification were performed from $1.5 \mu \mathrm{g}$ of zebrafish genomic DNA prepared from adults of $\mathrm{AB}$ line using the primers POU1 and POU2r. The cycle included a 1-min denaturation step at $94^{\circ} \mathrm{C}$, a $1-$ min annealing step at $50^{\circ} \mathrm{C}$, and a 2 -min extension step at $72^{\circ} \mathrm{C}$. After the amplification cycles, the reaction was followed by a final extension at $72^{\circ} \mathrm{C}$ for $7 \mathrm{~min}$ to complete the DNA synthesis. PCR products of $\sim 360 \mathrm{bp}$ length were cloned after insertion into pBluescript II SK + (Stratagene) and subjected to DNA sequence analysis. One clone, GP-3, containing an Oct-3-like POU domain, was used as a probe to screen a Lambda ZAPII cDNA library constructed from RNA of gastrula (6-9 hr) embryos (a kind gift from Dr. D. J. Grunwald, University of Utah, Salt Lake City).

\section{Northern blot analyses}

Total RNA was prepared by the acid guanidinium thiocyanate/ phenol/cloroform extraction method (Chomczynski and Sacchi 1987). Poly(A $)^{+}$RNA was purified from total RNA using oligo(dT)-latex (Oligotex-dT30, Roche). Ten micrograms of total RNA prepared from embryos of various stages (reared at $28.5^{\circ} \mathrm{C}$ ) and adult ovary or $2 \mu \mathrm{g}$ of poly $|\mathrm{A}\rangle^{+}$RNA of adult liver, intestine, and brain were separated by formaldehyde-containing $1.0 \%$ agarose gel (Sambrook et al. 1989) and blotted onto a Hybond $\mathrm{N}^{+}$filter (Amersham). Loading of the same amount of RNA was confirmed by ethidium bromide staining of the gel before Northern transfer. The filter was subjected to hybridization with a ${ }^{32} \mathrm{P}$-labeled probe that represented the $3^{\prime}$ region of pou2 (AccI-Xbal fragment; position 1381-2213), excluding the conserved POU domain. The hybridization buffer contained $6 \times$ SSC, $5 \times$ Denhardt's solution, $50 \mu \mathrm{g} / \mathrm{ml}$ of sonicated calf thymus DNA, and $0.5 \%$ SDS. After prehybridization, the filter was incubated with a new hybridization buffer containing the ${ }^{32} \mathrm{P}$ labeled probe $\left(1 \times 10^{6} \mathrm{cpm} / \mathrm{ml}\right)$ at $57^{\circ} \mathrm{C}$ for $16 \mathrm{hr}$. The filter was then washed to a final stringency of $0.1 \times \mathrm{SSC}$ at $57^{\circ} \mathrm{C}$. The radioactive signals were detected by Fujix BAS2000 Bio-imaging analyzer (Fuji photo film).

\section{In situ hybridization}

DIG-11-UTP-labeled single-stranded sense and antisense RNA probes were generated by in vitro transcription from a linearized plasmid clone containing the same cDNA fragment (AccI-XbaI) as used in the Northern blot analysis, according to the manufacturer's instructions for the DIG RNA labeling kit (Boehringer Mannheim, Mannheim, Germany). The embryos were fixed with $4 \%$ paraformaldehyde/PBS overnight at $4^{\circ} \mathrm{C}$.

For in situ hybridization to frozen sections, the fixed embryos were washed with PBS at $4^{\circ} \mathrm{C}$, frozen on dry ice, and cut at 10 $\mu \mathrm{m}$. Hybridization and washing were performed essentially as described (Takeda et al. 1992). Immunological detection was carried out according to the manufacturer's instructions for the DIG detection kit (Boehringer Mannheim).

For whole-mount in situ hybridization, the fixed embryos were transfered to vials filled with $100 \% \mathrm{MeOH}$ for $5 \mathrm{~min}$ after washing out paraformaldehyde with PBS at $4^{\circ} \mathrm{C}$. The $\mathrm{MeOH}$ was exchanged after $5 \mathrm{~min}$, and the vials were stored at $-20^{\circ} \mathrm{C}$ until further treatment. All further steps were performed at room temperature unless stated otherwise. The embryos were incubated twice in PBST (PBS/0.1\% Tween 20) for $5 \mathrm{~min}$, and a second fixation with $4 \%$ paraformaldehyde/PBS (20 min) was followed by two more washes with PBST.

The embryos were transferred to a microtiter plate containing hybridization mixture $(5 \times \mathrm{SSC}, 50 \mu \mathrm{g} / \mathrm{ml}$ of heparin, $100 \mu \mathrm{g} / \mathrm{ml}$ of sonicated calf thymus DNA, $10 \mu \mathrm{g} / \mathrm{ml}$ of yeast tRNA, $50 \%$ formamide) and incubated for at least $1 \mathrm{hr}$. The hybridization mixture was then replaced by the same mixture containing DIG-labeled RNA probe $(100 \mathrm{ng} / \mathrm{ml})$, and the embryos were incubated at $55^{\circ} \mathrm{C}$ overnight. After a rinse with $5 \times \mathrm{SSC}$, embryos were washed in $2 \times \mathrm{SSC} / 50 \%$ formamide at $65^{\circ} \mathrm{C}$ for $1 \mathrm{hr}$ and treated with RNase $A(20 \mu \mathrm{g} / \mathrm{ml})$ at $37^{\circ} \mathrm{C}$ for $1 \mathrm{hr}$. Thereafter, successive washing steps were carried out as follows: $2 \times$ $\mathrm{SSC}$ at $37^{\circ} \mathrm{C}$ three times for $10 \mathrm{~min}, 2 \times \mathrm{SSC} / 50 \%$ formamide at $65^{\circ} \mathrm{C}$ for $1 \mathrm{hr}, 2 \times \mathrm{SSC}$ at $55^{\circ} \mathrm{C}$ for $15 \mathrm{~min}, 0.2 \times \mathrm{SSC}$ at $55^{\circ} \mathrm{C}$ for $15 \mathrm{~min}$, and PBST twice for $5 \mathrm{~min}$.

Embryos were blocked for at least $1 \mathrm{hr}$ in blocking solution $(0.2 \%$ Tween $20,0.2 \%$ Triton X-100, $2 \%$ fetal calf serum in PBS). Alkaline-phosphatase (AP)-coupled anti-DIG Fab fragments (1:8000 dilution in blocking solution) were added in fresh blocking solution. After overnight incubation at $4^{\circ} \mathrm{C}$, embryos were washed three times with blocking solution for $30 \mathrm{~min}$ and three times with AP reaction buffer $(100 \mathrm{~mm}$ Tris- $\mathrm{HCl}$ at $\mathrm{pH} 8.0$, $50 \mathrm{mM} \mathrm{MgCl}_{2}, 100 \mathrm{mM} \mathrm{NaCl}, 0.1 \%$ Tween $20,1 \mathrm{~mm}$ levamizole) for $10 \mathrm{~min}$. Detection was performed in AP reaction buffer with NBT and X-phosphate added as described in the instruction manual of the DIG detection kit (Boehringer Mannheim). The reaction was stopped when the background levels became high 
(usually for $4-10 \mathrm{hr}$ ). The specimens were stored in $4 \%$ paraformaldehyde/PBS.

The probe for pax $[z f-b]$ was obtained by RT-PCR, followed by screening of our cDNA library made from 24-h embryos. The SacI-SmaI fragment, which excludes both the paired domain and the 3 ' noncoding region, was subcloned into pBluescript II $\mathrm{SK}+$ and was used as a template for the synthesis of DIG-labeled RNA probe. The HincII fragment of zebrafish $T$ cDNA (Schulte-Merker et al. 1992), which excluded its 3' end of noncoding region, was also sublconed into pBluescript II SK + and used as a template for the probe.

\section{Analyses of alternative splicing}

Two primers (POU2-5s and POU2-6r) were synthesized to amplify the DNA fragment corresponding to the Pou2 POU domain from zebrafish genomic DNA. The DNA fragment generated by PCR using these primers, which was $\sim 2.2 \mathrm{~kb}$ larger than that obtained when PCR was performed on cDNA, was subcloned and sequenced.

To determine the relative abundance of $t$-pou2 to pou2 transcripts, RT-PCR was performed. One primer (POU2-8r) was downstream of the POU homeo domain; the others (POU2-7s and POU2-6r) flanked the differential region of pou2/t-pou2 cDNA. The POU2-7s primer was labeled beforehand using $\left[\gamma^{32} \mathrm{P}\right]$ ATP (Amersham) and T4 polynucleotide kinase. cDNA primed with POU-8r from $5 \mu \mathrm{g}$ of total RNA was used as a template for subsequent PCR amplification of 20 cycles using POU2-7s and POU2-6r primers. Linear amplification on both cDNAs was confirmed up to 25 cycles. It was also confirmed that amplification was quantitative at 20 cycles between 1 and $10 \mu \mathrm{g}$ of RNA used for cDNA synthesis (Fig. 7C,D). This PCR generated a 184-bp fragment for pou2 cDNA and a 180-bp fragment for $t$-pou2 cDNA, which were analyzed by a sequencing gel. The relative abundance of these two products was determined by measuring the radioactivity in each band with a Fujix BAS2000 Bio-imaging analyzer. Three to four independent experiments were performed at each stage. The sequences of the oligonucleotides used are as follows: POU2-5s, 5'-CCACCATGGAGACTCTGACTACTGAAGATT-3'; POU2-6r, 5'-ATCAATACTGTGCTTCAACACACTCGTCAT-3'; POU2-7s, $5^{\prime}$ CGTTCTGCTCTAGAATCGTA-3' ${ }^{\prime}$ and POU2-8r, 5' -GGGATGGCATGTATAAGGCA-3'.

\section{In vitro translation and mobility-shift assay}

RNA was synthesized in vitro using the mCAP RNA capping kit (Stratagene) from pou2 cDNA (residues 168-2386 in Fig. 1), which had been inserted in the pBluescript II SK + plasmid at the $X$ hoI-EcoRI site. Because $t$-pou2 cDNA (clone 2-5) lacked a $3^{\prime}$ end noncoding region (residues 1957-2386), a PflMl fragment from clone 2-5 (residues 465-1666) was inserted into the plasmid containing the pou2 cDNA, which had been digested with PflMl. Thus, the two constructs used in this study are identical except for a 4-base deletion in the t-pou2 POU domain. These plasmids were linearized, and the sense RNA was made using a T7 RNA polymerase (Stratagene). RNA (1 $\mu \mathrm{g})$ used for in vitro translation reaction in rabbit reticulocyte lysate (Stratagene) in the presence of $\left[{ }^{35} \mathrm{~S}\right]$ methionine (DuPoint) was added to the reaction mixture. The labeled products were analyzed by $10 \%$ SDS-PAGE.

Of $50 \mu \mathrm{l}$ volume of the in vitro translation reaction, $5 \mu \mathrm{l}$ was used for mobility-shift DNA-binding assay as described elsewhere (Maekawa et al. 1989). wt-kp and mut-kp doublestranded oligonucleotides were synthesized based on the se- quence of the immunoglobulin $\mathrm{k}$-chain promotor (Rosner et al. 1990). They are as follows:

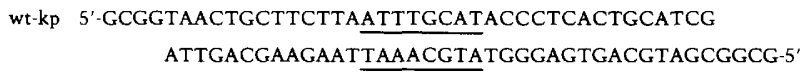

mut-kp 5'-GCGGTAACTGCTTCTTACAAGTGTGACCCTCACTGCATCG ATTGACGAAGAATGTTCACACTGGGAGTGACGTAGCGGCG-5

The underlined sequence in wt-kp is the consensus octamer motif. Probes were labeled using the Klenow fragment of DNA polymerase I (Pharmacia) and $\left[{ }^{32} \mathrm{P}\right] \mathrm{dCTP}$ (Amersham). Competition experiments included 100-fold excess of unlabeled oligonucleotides in the binding reactions.

\section{Microinjection of embryos with RNA}

Capped RNAs were synthesized as described above using the same pou2 and $t$-pou2 constructs and were diluted to $0.05-0.3$ $\mu \mathrm{g} / \mu \mathrm{l}$ with distilled water. The RNA synthesis was done in at least two independent experiments. In each experiment, both pou2 and $t$-pou2 RNAs were injected side by side into the same batch of fertilized eggs to avoid a batch variation of eggs. For the lac $Z$ construct, the lac $Z \mathrm{cDNAs}$ were inserted into pBluescript II KS + containing a poly(A) tract at the PstI site (Yamazaki et al. 1992). Fertilized eggs at the one-cell stage were injected with $\sim 300 \mathrm{pl}$ of RNA solution through a glass micropipette and allowed to develop at $28.5^{\circ} \mathrm{C}$ in one-third zebrafish Ringer solution $(1 \times$ Ringer is $116 \mathrm{~mm} \mathrm{NaCl}, 2.9 \mathrm{~mm} \mathrm{KCl}, 5 \mathrm{~mm}$ HEPES, 1.8 $\mathrm{mM} \mathrm{CaCl}_{2}$, at $\left.\mathrm{pH} 7.2\right)$ containing antibiotics $(50 \mathrm{U} / \mathrm{ml}$ of penicillin $\mathrm{G}$ and streptomycin).

\section{RNase protection assay}

RNA-injected or uninjected embryos were collected and homogenized in a lysis buffer $(45 \mu$ l for every 10 embryos; $4 \mathrm{M}$ guanidine thiocyanate, $25 \mathrm{~mm}$ sodium citrate, and $0.5 \%$ sarcosyl). For hybridization, $45 \mu \mathrm{l}$ of each sample was transferred to tubes containing $2 \times 10^{5} \mathrm{cpm}$ of $\left[{ }^{32} \mathrm{P}\right] \mathrm{UTP}$-labeled antisense probe diluted in $5 \mu \mathrm{l}$ of lysis buffer. To confirm the linearity of the protected signal, the sample RNA was diluted with a lysis buffer and hybridized with the radioactive antisense probe. As a negative control, the lysis buffer containing $100 \mu \mathrm{g}$ of yeast tRNA was hybridized with the probe. After an overnight hybridization at $55^{\circ} \mathrm{C}$, the samples were mixed with $500 \mu l$ of RNase cocktail $[20 \mu \mathrm{g}$ of RNase A, 500 units of RNase T1 (Sigma) in $10 \mathrm{~mm}$ Tris- $\mathrm{HCl}$ (pH 7.5), $300 \mathrm{~mm} \mathrm{NaCl}, 5 \mathrm{~mm}$ EDTA] and incubated for $1 \mathrm{hr}$ at $37^{\circ} \mathrm{C}$. They were then treated with proteinase $\mathrm{K}(0.2 \mathrm{mg} / \mathrm{ml})$ for $45 \mathrm{~min}$ at $37^{\circ} \mathrm{C}$. The protected RNAs were precipitated with isopropanol in the presence of 3 ng of yeast tRNA, and the pellets were resupended in $10 \mu \mathrm{l}$ of loading buffer $188 \%$ formamide, $10 \mathrm{~mm}$ EDTA, $1 \mathrm{mg} / \mu \mathrm{l}$ each of xylene, cyanol, and bromphenol blue). These samples were analyzed by a sequencing gel with a molecular maker (DNA sequence reaction). The relative abundance of protected signals was determined by measuring the radioactivity in each band with a Fujix BAS2000 Bio-imaging analyzer. Two independent experiments were performed.

For making $\left.{ }^{32} \mathrm{P}\right] \mathrm{UTP}$-labeled antisense probe, the KpnI$B a m H I$ fragment (residues $168-338$ plus 16 bases of the vector polylinker sequence) was inserted into the T3T7-18 vector (BRL). The RNA probe was synthesized in vitro by T3 RNA polymerase (Maxiscript kit, Ambion) in the presence of [ ${ }^{32}$ P]UTP (DuPont) from the plasmid linearized with EcoRI. Thus, the lengths of the probes and protected fragments for endogenous and injected synthetic RNAs were 245, 171, and 187 , respectively. 


\section{Acknowledgments}

We thank Dr. C.B. Kimmel for providing the $A B$ line of zebrafish, Drs. D.J. Grunwald, R. Riggleman, and K. Helde for providing the cDNA library, Dr. S. Schulte-Merker for providing zebrafish $T$ cDNA, and Dr. H. Mori for providing the $l a c Z$ construct. We also thank Dr. S. Yasugi of the Tokyo Metropolitan University for critical reading of the manuscript. We acknowledge Mr. S. Watanabe for making the cDNA library of 24-hr embryos. This work was supported in part by a Special Grant for Promotion of Research from the Institute of Physical and Chemical Research and by grants-in-aids of the Ministry of Education, Science, and Culture of Japan.

The publication costs of this article were defrayed in part by payment of page charges. This article must therefore be hereby marked "advertisement" in accordance with 18 USC section 1734 solely to indicate this fact.

\section{Note added in proof}

The sequence data of pou2 have been deposited in the EMBL/ GenBank data libraries.

\section{References}

Baker, B.S. 1989. Sex in flies: The splice of life. Nature 340: $521-524$.

Birnstiel, M.L., M. Busslinger, and K. Strub. 1985. Transcription termination and $3^{\prime}$ processing: The end is in site Cell 41: 349-359.

Chomczynski, P. and N. Sacchi. 1987. Single-step method of RNA isolation by acid guanidinium thiocyanate-phenolchloroform extraction. Anal. Biochem. 162: 156-159.

Cunliffe, V. and J.C. Smith. 1992. Ectopic mesoderm formation in Xenopus embryos caused by widespread expression of a Brachyury homologue. Nature 358: 427-430.

Davis, R.L., H. Weintraub, and R.B. Lassar. 1987. Expression of a single transfected cDNA converts fibroblasts to myoblasts. Cell 56: 607-617.

Foulkes, N.S. and P. Sassone-Corsi. 1992. More is better: Activators and repressors from the same gene. Cell 68: 411-414.

Frank, D. and R.M. Harland. 1992. Localized expression of a Xenopus POU gene depends on cell-autonomous transcriptional activation and induction-dependent inactivation. $D e$ velopment 115: 439-448.

He, X., M.N. Tracy, D.M. Simmons, H.A. Ingraham, L.W. Swanson, and M.G. Rosenfeld. 1989. Expression of a large family of POU-domain regulatory genes in mammalian brain development. Nature 340: 35-42.

Herrmann, B.G., S. Labeit, A. Poustka, T.R. King, and H. Lehrach. 1990. Cloning of the $T$ gene required in mesoderm formation in the mouse. Nature 343: 617-622.

Hinkley, C.S., J.F. Martin, D. Leibham, and M. Perry. 1992. Sequential expression of multiple POU proteins during amphibian early development. Mol. Cell. Biol. 12: 638-649.

Ho, R.K. 1992. Cell movements and cell fate during zebrafish gastrulation. Development (Suppl.) 65-73.

Ho, R.K. and C.B. Kimmel. 1993. Commitment of cell fate in the early zebrafish embryos. Science 261: 109-111.

Hopwood, H.D., A. Pluck, and J.B. Gourdon. 1989. MyoD expression in the forming somites is an early response to mesoderm induction in Xenopus embryo. EMBO I. 8: 34093417.

Ingraham, H.A., S.E. Flynn, J.W. Voss, V.R. Albert, M.S. Kapiloff, L. Wilson, and M.G. Rosenfeld. 1990. The POU-specific domain of Pit-1 is essential for sequence-specific, high affin- ity DNA binding and DNA-dependent Pit-1-Pit-1 interactions. Cell 61: 1021-1033.

Johansen, T., U. Moens, T. Holm, A. Fjose, and S. Krauss. 1993. Zebrafish pou/cl: A divergent POU familiy gene ubiquitously expressed during embryogenensis. Nucleic Acids Res. 21: 475-483.

Kane, D.A., R.M. Warga, and C.B. Kimmel. 1992. Mitotic domains in the early embryos of the zebrafish. Nature 360: $735-737$.

Kimmel, C.B. 1989. Genetics and early development of zebrafish. Trends. Genet. 5: 283-288.

Kimmel, C.B. and R.D. Law. 1985. Cell lineage of zebrafish blastomeres. II. Formation of the yolk syncytial layer. Dev. Biol. 108: 86-93.

Kimmel, C.B. and R.M. Warga. 1986. Tissue-specific cell lineages originate in the gastrula of the zebrafish. Science 231: 365-368.

Kozak, M. 1986. Point mutations define a sequence flanking the AUG initiator codon that modulates translation by eukaryotic ribosomes. Cell 44: 283-292.

Krauss, S., T. Johansen, V. Korzh, and A. Fjose. 1991. Expression of the zebrafish paired box gene pax $[z f-b]$ during early neurogenesis. Development 113: 1193-1206.

Krauss, S., M. Maden, N. Nolder, and S.W. Wilson. 1992. Zebrafish pax $[b]$ is involved in the formation of the midbrainhindbrain boundary. Nature 360: 87-89.

Li, S., E.B. Crenshaw III, E.J. Rawson, D.M. Simmons, L.W. Swanson, and M.G. Rosenfeld. 1990. Dwarf locus mutants lacking three pituitary cell types result from mutations in the POU-domain gene pit-1. Nature 347: 528-533.

Lin, S., W. Long, J. Chen, and N. Hopkins. 1992. Production of germ-line chimeras in zebrafish by cell transplants from genetically pigmented to albino embryos. Proc. Natl. Acad. Sci. 89: 4519-4523.

Maekawa, T., H. Sakura, C. Knei-Ichii, T. Sudo, T. Yoshimura, J. Fujisawa, M. Yoshida, and S. Ishii. 1989. Leucine zipper structure of the protein CRE-BP1 binding to the cyclic AMP response element in brain. EMBO J. 8: 2023-2028.

Matsuzaki, T., H. Amanuma, and H. Takeda. 1992. A POUdomine gene of zebrafish, specifically expressed in the developing neural tissues. Biochem. Biophys. Res. Commun. 187: 1446-1453.

Monuki, E.S., R. Kuhn, G. Weinmaster, B. Trapp, and G. Lemke. 1990. Expression and activity of the POU transcription factor SCIP. Science 249: 1300-1303.

Okamoto, K., H. Okazawa, A. Okuda, M. Sakai, M. Muramatsu, and H. Hamada. 1990. A novel octamer binding transcription factor is differentially expressed in mouse embryonic cells. Cell 60: $461-472$.

Radovick, S., M. Nations, Y. Du, L.A. Berg, B.D. Weintraub, and F.E. Wondisforld. 1992. A mutation in the POU-homeo domain of pit-1 responsible for combined pituitary hormone deficiency. Science 257: 1115-1118.

Rosenfeld, M.G. 1991. POU-domain transcription factors: pouer-ful developmental regulators. Genes \& Dev. 5: 897-907.

Rosner M.H., M.A. Vigano, K. Ozato, P.M. Timmons, F. Poirier, P.W.J. Rigby, and L.M. Staudt. 1990. A POU-domain transcription factor in early stem cells and germ cells of the mammalian embryo. Nature 345: 686-692.

Rutz, R., and S. Hauschka. 1982. Clonal analysis of vertebrate myogenesis. VII. Heritability of muscle colony type through sequential subclonal passages in vitro. Dev. Biol. 91: 103110.

Sambrook, J., E.F. Frisch, and T. Maniatis. 1989. Molecular cloning: A laboratory manual. Cold Spring Harbor Laboratory Press, Cold Spring Harbor, New York. 
Schöler, H.R. 1991. Octamania: The POU factors in murine development. Trends Genet. 7: 323-329.

Schöler, H.R., A.K. Hatzopoulos, R. Balling, N. Suzuki, and P. Gruss. 1989. A family of octamer-specific proteins present during mouse embryogenesis: Evidence for germline-specific expression of an oct factor. EMBO J. 8: 2543-2550.

Schöler, H.R., S. Ruppert, N. Suzuki, K. Chowdhury, and P. Gruss. 1990. New type of POU domain in germ line-specific protein Oct-4. Nature 344: 435-439.

Schulte-Merker, S., R.K. Ho, B.G. Herrmann, and C. NüssleinVolhard. 1992. The protein product of the zebrafish homologue of the mouse $T$ gene is expressed in nuclei of the germ ring and the notochord of the early embryo. Development 116: 1021-1032.

Stoykova, A.S., S. Sterrer, J.R. Erselius, A.K. Hatzopoulos, and P. Gruss. 1992. Mini-Oct and Oct-2c: Two novel, functionally diverse murine Oct-2 gene products are differentially expressed in the CNS. Neuron 8: $541-558$.

Strehlow, D. and W. Gilbert. 1993. A fate map for the first cleavages of the zebrafish. Nature 361: 451-453.

Suzuki, N., N. Rohdewohld, T. Neuman, P. Gruss, and H.R. Schöler. 1990. Oct-6: A POU domain transcription factor expressed in embryonal and stem cells and in the developing brain. EMBO I. 9: 3723-3732.

Takeda, H., A. Yoshiki, S. Nishikawa, S. Nishikawa, T. Kunisada, T. Sakakura, H. Amanuma, and M. Kusakabe. 1992. Expression of c-kit, proto-oncogene of the murine $W$ locus, in cerebella of normal and neurological mutant mice: Immunohitochemical and in situ hybridization analysis. Differentiation 51: 121-127.

Treacy, M.N., X. He, and M.G. Rosenfeld. 1991. I-POU: A POUdomain protein that inhibits neuron-specific gene activation. Nature 350: 577-584.

Treacy, M.N., L.I. Neilson, E.E. Turner, X. He, and M.G. Rosenfeld. 1992. Twin of I-POU: A two amino acid difference in the I-POU homeodomain distinguishes an activator from an inhibitor of transcription. Cell 68: 491-505.

Warga, R.M. and C.B. Kimmel. 1990. Cell movements during epiboly and gastrulation in zebrafish. Development 108: $569-580$.

Whitfield, T., J. Heasman, and C. Wylie. 1993. XLPOU-60, a Xenopus POU-domain mRNA, is oocyte-specific from very early stages of oogenesis, and localized to presumptive mesoderm and ectoderm in the blastula. Dev. Biol. 155: 361370.

Wylie, C., A. Snape, J. Heaseman, and J.C. Smith. 1987. Vegetal pole cells and commitment to form endoderm in Xenopus laevis. Dev. Biol. 119: 496-502.

Yamazaki, M., H. Mori, K. Araki, K.J. Mori, and M. Mishina. 1992. Cloning, expression and modulaiton of a mouse NMDA receptor subunit. FEBS Lett. 300: 39-45. 


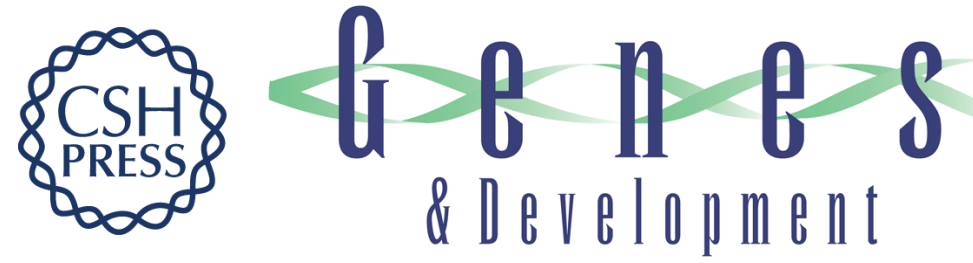

\section{A novel POU domain gene, zebrafish pou2: expression and roles of two alternatively spliced twin products in early development.}

H Takeda, T Matsuzaki, T Oki, et al.

Genes Dev. 1994, 8:

Access the most recent version at doi:10.1101/gad.8.1.45

References This article cites 45 articles, 11 of which can be accessed free at:

http://genesdev.cshlp.org/content/8/1/45.full.html\#ref-list-1

License

Email Alerting

Service

Receive free email alerts when new articles cite this article - sign up in the box at the top right corner of the article or click here.

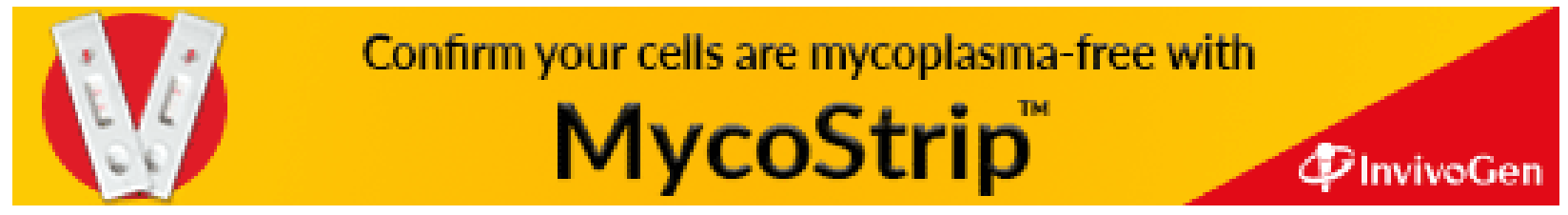

